\title{
On Liberatory Strategies of Digital Nomads
}

Abstract: The article presents selected threads of poststructuralist discourses, such as posthumanism and post-anarchism, to point out the affirmative understanding of the changes in human subjectivity and identity within the networked reality of transnational capitalism. The starting point for the argument presented in the text is Rosi Braidotti's concept of the nomadic subject, functioning in a post-anthropocentric world inhabited by non-anthropic consciousness and anthropotechnical hybrids. The identity of such a nomadic subject is variable, flexible, and queer. The strategies of digital nomads, avoiding permanent points/places, and thus eluding essentialism, are presented as liberatory strategies of resistance.

Keywords: technology, nomad, queer, post-humanist, post-anarchism, anarcho-transhumanism

We are everybody and we are nobody. We can't be stopped, because we don't even exist. ${ }^{1}$

Lewis Call

\section{Points of Entry (Post-Humanities and Post-Anarchism)}

Among the discourses describing (and constructing) the relations between man and technology, those simultaneously critical with respect to the technological progress, yet fundamentally assuming its, at least relative, affirmation, appear to be the most interesting. This means - among others - that although such narratives are sensitive to the oppressive impact of technology, they do acknowledge its emancipatory potential. Inscribing technology into the horizon of human experience, these discourses answer the key question: How to think about the progress of techno-science in the context of the reformulations of human subjectivity and identity in positive terms?

1. Lewis Call, "Editorial - Post-anarchism Today," Anarchist Developments in Cultural Studies, 1/2010, 10. 
One of such discourses is that of technological gnosis, which concept may be construed as an interpretation of transhumanist narrations. It assumes the teleological evolution of technology and technological progress, as a result of which man - as an intellectual and spiritual construct - is to deliver himself from matter and advance to the plane of virtual/spiritual states. Although gnosis understood in this way is secular (in comparison with ancient Gnosticism), and although it subjects the transcendent authority to gradual immanentization, it nonetheless remains an element of the (meta)narration of idealist provenance. ${ }^{2}$

In this text, however, I focus on other discourses. Owing to the development of the post-humanist studies, we can now conceive of subjectivity as hybrid, post-anthropocentric, and, above all, nomadic. In this context, post-anarchism perpetuating and furthering the legacy of anarchism - exposes the essentialist opposition between power and man, thus becoming an embodiment of libertarian sensitivity in the network-structured reality. Post-anarchist discourses are largely based on post-structural thought, which entails, among others, a departure from Cartesian dualism and cogito towards Spinoza's monism, and a turn towards process ontology (which "posit[s] the primacy of relations over substances" ${ }^{3}$ ) and towards new materialism. ${ }^{4}$ The second, and perhaps more important, point of reference in the context of the debate on post-humanist identity, is anarcho-transhumanism (whose assumptions are explicated in An Anarchist-Transhumanist Manifesto ${ }^{5}$ and in several secondary texts).

2. I addressed the question of technognosis in my monograph dedicated to the oeuvre of Jacek Dukaj - see Piotr Gorliński-Kucik, TechGnoza, uchronia, science fiction. Proza Jacka Dukaja [TechGnosis, Uchronia, Science Fiction. On Jacek Dukaj's Prose] (Katowice: University of Silesia Press, 2017), and in the following article: Piotr Gorliński-Kucik, "Głos budującego na pustyni. Kryptoteologia gnozy technologicznej" [The Voice of One Building in the Desert. The Cryptotheology of Technological Gnosis], FA-art, no. 105, 3/2016, 45-63.

3. Rosi Braidotti, "Posthuman, All Too Human. Towards a New Process Ontology," Theory, Culture \& Society 23 (7-8), 2006.

4. In the context of new materialism, ontology should be understood as "a fundamental reflection - necessary in all areas of scholarship and science - on what the reality under study consists of and how it is organized." (Joanna Bednarek, "Zwrot posthumanistyczny a ontologia" [Post-humanist Turn versus Ontology], Praktyka Teoretyczna, no. 14 2014, 4/2014, 248). The point is then to ask not only of what the world is made, but how it is made, because "matter, whether understood as production or as self-organization, is one common plane, capable of containing everything beginning with the stratification of rock formations and finishing with art and politics." Bednarek, "Zwrot posthumanistyczny a ontologia"; Cf: Rick Dolphijn, Iris van der Tuin, New Materialism: Interviews \& Cartographies (Ann Arbor: Open Humanities Press, 2012). http://hdl. handle.net/2027/spo.11515701.0001.001.

5. At this point, I would like to emphasize an important difference: anarcho-trans-humanist texts often embrace the poetics of the manifesto, while all others follow the principles of academic or essayistic - writing. 
Without dismissing its own critical apparatus, anarcho-transhumanism perceives technology as an instrument in the struggle for freedom, and thus offers me a useful tool for my own analysis.

My goal is to make an attempt at a description of the subjectivity of digital nomads. To attain it, I aim to explore the fluid (queer) identity of the nomadic subject and to explore several strategies of libertarian resistance to technological oppression that in the mselves are based on the use of technology. "It is a historical fact that the great emancipatory movements of postmodernity are driven and fueled by the resurgent 'others"' $-\mathrm{I}$ am, therefore, interested in the discourses of freedom, sharing their sensitivity to violence-based relations, which today, in the face of the enfeeblement of nation states, are funded by transnational capitalism. This “'difference engine' [...] promotes the marketing of pluralistic differences and the commodification of the existence, the culture, the discourses of 'others,' for the purpose of consumerism. As a consequence, the global system of the post-industrial world produces scattered and poly-centered, profit-oriented power relations."

Such a state of affairs determines our subjectivities:

The commodification of differences turned the 'others' into objects of consumption, granting them alternatively a familiar and a threatening quality that bypasses the doors of the dialectics. We have entered into a zigzagging pattern of dissonant nomad subjects. ${ }^{8}$

"The ideal of 'Man"' emerged out of ancient humanism and gradually assumed the form of a Eurocentric, universalist cultural practice founded on rationalism. Post-humanist attempts at new definitions of subjectivity are motivated by the exhaustion of this model, and thus also driven by the exhaustion of the productivity of anthropocentrism and anthropomorphism.

The opposition between nature and culture has become invalidated, among other factors, as a result of technological progress. Consequently, "[t]he profoundly anthropocentric core of the Humanities is displaced by [the] complex reconfiguration of knowledge dominated by science studies and technological information."10

6. Rosi Braidotti, "Posthuman Relational Subjectivity and the Politics of Affirmation," in: Relational Architectural Ecologies. Architecture, Nature and Subjectivity, ed. Peg Rawes (London and New York: Routledge, 2013), 23.

7. Braidotti, "Posthuman Relational Subjectivity and the Politics of Affirmation," 24.

8. Braidotti, "Posthuman Relational Subjectivity and the Politics of Affirmation," 25.

9. Rosi Braidotti, "Working towards the Posthumanities," Trans-Humanities, vol. 7, no. 1, Feb. 2014 (Seoul: Ewha Womans University Press, 2014), 161.

10. Braidotti, "Working towards the Posthumanities," 163. 
If man has ceased to be "the measure of all things"11 and no longer is the "king of creation," then "[a] non-anthropocentric approach deconstructs species supremacy, but it also inflicts a blow to notions of human nature, uniqueness or exceptionality." ${ }^{2}$ In effect, we shift from ego-logical to eco-logical thinking.

Heteronomy and relationality, as well as radical immanence, enforce the interdisciplinarity of post-humanist studies: "This new knowing subject is a complex assemblage of human and non-human, planetary and cosmic, given and manufactured [...]."13 The relation of the zoe-techno-body to its environment is founded upon their interdependence "through a structure of mutual flows and data transfers [...]"14 - and, on that premise, it is possible to assert that the body-machine is "an embodied affective and intelligent entity that captures, processes, and transforms energies and forces." 15 The nomadic subjects is "[...] an in-between: a folding in of external influences, and a simultaneous folding on of affects. As a mobile entity - mobile in space and time this subject is continually in process but is also capable of lasting through sets of discontinuous variations while remaining extraordinarily faithful to itself." ${ }^{\prime 6}$ The post-anthropocentric and nomadic subjectivity may also be conceived of (as Braidotti, quoting Haraway, points out) in the context of post-humans, non-anthropic consciousnesses, and all the Others, who are anthropotechnical hybrids - and the litmus paper of pop culture seems to indicate that empathy is starting to outweigh fear. ${ }^{17}$

11. The phrase attributed to Protagoras of Abdera (alluded to, among others, in Plato's dialogue of the Theatetus) has been disavowed on numerous occasions. For instance, in his novel The End of "The Concord of Nations," Teodor Parnicki does it in a laconically uncompromising manner, having a nameless soldier ask Theophilus (committing suicide) the question: "Which man, my lord?”- Teodor Parnicki, Koniec “Zgody Narodów”. Powieść z roku 179 przed narodzeniem Chrystusa, [The End of "The Concord of Nations." A Novel from the Year 179 Before Christ.] wyd. II (Warszawa: Instytut Wydawniczy PAX, 1957), 551.

12. Braidotti, "Working towards the Posthumanities," 164.

13. Braidotti, "Working towards the Posthumanities," 165.

14. Rosi Braidotti, "The Politics of Life as Bios/Zoe," in: Bits of Life. Feminism at the Intersections of Media, Bioscience, and Technology, ed. Anneke Smelik and Nina Lykke (Seattle and London: University of Washington Press, 2008), 182.

15. Braidotti, "The Politics of Life as Bios/Zoe," 183.

16. Braidotti, "The Politics of Life as Bios/Zoe," 187.

17. I am referring to films set in the SF convention in which Cassandran visions of the rebellion of the machines - predominant in Terminator or in Matrix - have been superseded by visions of the future such as those presented in WALL.E (dir. Andrew Stanton, USA, 2008), Her (dir. Spike Jonze, USA, 2013), Chappie (dir. Neill Blomkamp, RPA-USA, 2015) or in the television series Westworld (USA, 2016), in which the post-human subjects have been constructed not only as empathetic, but also suffering oppression. See: Piotr Gorliński-Kucik, "Między nadzieją a paranoją. O post-człowieku w filmach science fiction (na kilku przykładach)" [Between Hope and Paranoia. 
Importantly, the discourses of freedom drawing on the tradition of 19th-century anarchism metamorphosed under the influence of post-structuralist theories ${ }^{18}$ (and therefore, for instance, became capable of emphasizing the anti-authoritarianism of May 1968 more strongly than ever). Eventually, also these discourses evolved into a constellation of critical theories characterized by libertarian sensitivity. They have redefined the understanding of the social contract, utopia (now seen as a conceptual alternative rather than a phantasm), or the revolutionary act.

Post-anarchism questions the notion of "human nature" which has its source in humanism, and thereby rejects the essentialist (Manichean) opposition of "evil" authority and "good" human nature. As a consequence, it changes the understanding of power and power-wielding authority (which, as such, cannot be avoided, but various forms of domination at which those in the positions of power attempt may be resisted) and emphasizes that it is impossible to transgress the limits of its logic (in other words: nothing outside the logic of power exists). Post-anarchism, then, is about mindfully deconstructing a variety of non-obvious forms of pressure: it meticulously scrutinizes symbolic orders generated by "monocentric" (e.g., capital-centric, phallogocentric) structures that produce identity models. That is why, in a sense, the evolution of forms of resistance to power began to resemble an arms race. Oppression, increasingly mediated by the network of relations and by the technosphere, requires sensitivity to subtle, non-obvious influences, to non-blatant trends ${ }^{19}$. Post-anarchism is a processual anarchism; it tends towards pan-anarchy.

An illustrative example of such thinking is Giorgio Agamben's ${ }^{20}$ analysis of the concept of the apparatus. ${ }^{21}$ The Italian philosopher addresses a concept already present in Foucault's system (as "the network [le reseau] that can be established

On the Post-Human in Science Fiction Films (A Handful of Case Studies)], Creatio Fantastica, no. $59,2 / 2018,109-122$.

18. The monograph Post-Anarchism. A Reader, edited by Duane Rousselle, Süreyyya Evren (London: Pluto Press, 2011), collects texts by authors of primary importance to the current, such as Duane Rousselle, Todd May, Saul Newman, Hakim Bay, or Lewis Call - and as such may be recommended as representative.

19. A polycentric network of diagonal and transverse connections that redistributes power may serve as a counterbalance to the networked reality. See: Erick Heroux, "PostAnarchia Repertoire," Anarchist Developments in Cultural Studies, 1/2010, 19-30. Heroux's article also offers valuable comments on representation and Lyotardian paralogy in the context of the post-anarchist strategies ("anarchism with many adjectives").

20. Giorgio Agamben, What Is an Apparatus? And Other Essays, trans. David Kishik and Stefan Pedatella (Stanford CA: Stanford University Press, 2009), 1-24.

21. Un dispositivo translates into apparatus in English and un dispositif in French. For more information about the genealogy of the concept and about its translations, see: Magdalena Nowicka, “'Urządzenie,' 'zastosowanie, ' układ' - kategoria dispositif u Michela Foucaulta, jej tłumaczenia i ich implikacje dla postfoucaultowskich analiz władzy" ['Apparatus,' 'Disposition,' 'System' - The Cat- 
between [...] elements"22), but he traces its origins as far back as to the Greek notion of oikonomia (a concept employed in the theology of the Holy Trinity as early as in Christian antiquity). Hence, in addition to the prisons, schools, and factories included by the author of The History of Sexuality, Agamben also populates the network with literature, philosophy, technology, and even language.

The philosopher categorizes beings into two groups/classes: "on the one hand, living beings (or substances), and on the other, apparatuses in which living beings are incessantly captured." ${ }^{23}$ The subjects, in turn, are situated between these classes; they arise as a product of their dynamics, emerging from the constant struggle between substances and apparatuses. An apparatus is therefore both a mechanism of subjectification (empowerment) and of the execution of power. In late capitalism, apparatuses not only produce subjects, but also affect reality through processes of de-subjectification: "A desubjectifying moment is certainly explicit in every process of subjectification." ${ }^{4}$ Today, we face the proliferation of subjectivity, which brings the intensity of the masquerade, inherent to every identity, to the extreme. This is an example of the subtle libertarian thought at work while analyzing the mechanisms of power: such a reflection may well be ascribed to the trend of post-structural anarchism. ${ }^{25}$

The second example of post-anarchist logic may be seen in the way in which Duane Rousselle and Jason Adams ${ }^{26}$ write about mediatization, expanding Hakim Bey's concept of immediatism far enough to accommodate the properties of the communication situation today. Bey's immediatism, opposing mediation and alienation, postulated directness and immediacy in the lived experience of art, at the same time constructing a broader libertarian project that would describe the subject's relationship with his or her environment. ${ }^{27}$ Rousselle and Adams note that the experience of mediation today is im-mediatized with particular vehemence, because it is - surprise, surprise - mediated by digital media:

egory of Dispositif in Michel Foucault: Its Translations and Its Implications for Post-Foucauldian Analyses of Power], Przegląd Socjologii Jakościowej, vol. VII, no 2, 2011, 94-110.

22. Foucault, quoted by Agamben, What Is an Apparatus?, 7.

23. Agamben, What Is an Apparatus?, 13.

24. Agamben, What Is an Apparatus?, 20.

25. However, scholarly opinions concerning Agamben's post-anarchism are divided. See: Leland De la Durantaye, Giorgio Agamben, A Critical Introduction (Stanford: Stanford University Press, 2009); cf. Lorenzo Fabbri, "From Inoperativeness to Action: On Giorgio Agamben's Anarchism," Radical Philosophy Review, vol. 14, no 1, 2011, 85-100.

26. Duane Rousselle, Jason Adams, "Anarchism's Other Scene. Materializing the Ideal and Idealizing the Material," Anarchist Developments in Cultural Studies, no 2, 2013, 1-9.

27. Hakim Bey, Immediatism (Edinburgh: AK Press, 1994). 
The "everyday" experience of the world as "unmediated" today [...] is an effect of a particular mode of perception, as it appears for a particular person, or a particular people, at a particular place, a particular time. ${ }^{28}$

The digitized power of today and contemporary capital are not based on the logic of mediation but, conversely, on that of immediatization - that is, they rely on a logic that renders the very conditions of this immediatization imperceptible.

Immediatization rerenders everything from art to philosophy, science to religion, and politics to love, so that they all reappear as the capitalized instantaneity, interactivity, and ubiquity that characterize experience in our network-centric media environment. ${ }^{29}$

Today, commodification is based on exchange value, and the refore the consumption of goods has become tantamount to their production - the viewer has become the producer of his own show performed in front of millions. "The greatest danger to aesthetics today (contra Bey) is not alienation from sensation by way of the mass media, but the sensation of disalienation by way of social media." 30 I believe that the best example in support of the above claim is the content posted to social media - especially the content broadcast live on Instagram, ${ }^{31}$ TikTok, or YouTube. It is through these media that the coverage of important social and political events - as well as gossip concerning the lives of online celebrities - reaches the audiences world-wide. Such media give one an illusory sense of the directness of the message, further reinforced by horizontal communication and the apparent lack of the sender. However, this communication is strongly mediated (im-mediatized) both by means of the hardware and software in use, but also by conventions or trends that follow memetic logic (all this is an apparatus). As such mediation is invisible at first glance, it fosters the formation of a false sense of communion with others in a situation which, in essence, epitomizes non-communication or alienation. How (and for what purpose) this apparatus works should be (and often is) the subject of careful consideration within humanities in general. Yet, analyses of this kind - collapsing (deconstructing) oppositions, and operating on the principle of drawing one's attention to more and more sophisticated forms

28. Rousselle, Adams, "Anarchism's Other Scene," 2.

29. Rousselle, Adams, "Anarchism's Other Scene," 3.

30. Rousselle, Adams, "Anarchism's Other Scene," 3.

31. The name "Instagram" is probably a derivative of the cluster "instant camera" (i.e., a Polaroid-type camera, or - nomen est omen - a camera developing pictures instantly) combined with the word "telegram." As such an etymology would suggest, Instagram serves the purpose of instant dispatch of photographs ready for publication immediately after they have been taken. 
of oppression in the networked reality - characterize post-anarchism. At the same time, their development brings to mind the (already mentioned) arms race.

\section{Some Bold Ideas (Towards Anarcho-Transhumanism)}

Thus, while Posthumanities allow one to reconsider the post-anthropocentric subjectivity (also in the context of the non-anthropic or anthropo-technological forms of consciousness), post-anarchism focuses upon the more and more sublimated effects of the apparatuses perceived as forms of oppression. The third element, key to our attempt at the description of the emancipatory strategies adopted by the digital nomads is (the allegedly paradoxical) anarcho-transhumanism. The closing sentences of An Anarchist-Transhumanism Manifesto read as follows: ${ }^{32}$

[...] we need to eliminate [...] these tools of destruction, undo the current power structures, and liberate ourselves from our mortal limitations. The combination of anarchist egalitarianism and ambitious transhumanist innovation is an unstoppable and unbelievably liberating force we cannot ignore.

We want to see a fair authentic transhumanist future, but one with anarchist values and the lack of massive human rights abuses. Brain/Mind will be liberated and freed from the shackles of the oppressive State and the tyranny of capitalism, and technological progress will aid our fight for the future! ${ }^{33}$

The sentence "technological progress will aid our fight for the future" is a thesis of paramount importance, because - according to the logic of terrorism - it reverses emphases: if, at times, technology proves to be the tool of oppression and violence, it may also serve as a tool aiding one's struggle for liberty.

Anarcho-transhumanism stresses the classical motifs of 19th-century thought such as collaboration or radical democracy - more strongly than does post-anarchism. Owing to this, to a certain degree, it reveals itself as utopian in character. Although it rests upon the fundament of transhumanism, anarcho-transhumanism clearly highlights its post-humanist background (and accentuates its kinship with Braidotti's thought ${ }^{34}$ ), while simultaneously disavowing anthropocentric

32. An Anarchist-Transhumanism Manifesto, https://docs.google.com/document/d/1wJrXYBXAmNH9zwyfgg1-yAYN_Cda-26pFCk0u_QhyBc/edit (03.06.2020). The most recent revisions were introduced to the document on 4 June 2019. The fact that the Manifesto is an effect of collective work - work that remains unfinished and, probably, is still ongoing - further emphasizes the character of Anarcho-Transhumanism as presented in the document itself.

33. An Anarchist-Transhumanism Manifesto.

34. "This notion of Transhumanism, as long as it does not promote or impose one form over others and one choice over others, is entirely compatible with the inclusiveness of Posthumanism" (An Anarchist-Transhumanist Manifesto). 
humanism: "As the bastard child of Enlightenment thought, anarchism rebels against the dominations woven into that tradition while embracing its liberatory elements." ${ }^{35}$ Matilde Marcolli states that trans-humanism requires libertarian thinking ${ }^{36}$ in order to prevent fears from turning into flesh - especially the fear of technological progress (such as the fear of the dominance of AI, which she dubs the "dark mythologies of modern age" ${ }^{37}$ ) and the fear of reinforced hierarchical power (e.g., the fear of the rule of posthumans over humans) trigger concern. The critical dimension of anarcho-transhumanism $(\mathrm{A}-\mathrm{H}+)$ becomes manifest in the fact that its advocates universally acknowledge the contribution of technology to racial, colonial, gender, or imperialist oppression.

Thus, while trans-humanism is a movement of an anthropocentric nature (as it overtly posits the self-evolution of homo sapiens without rejecting the concept of the human species as "the crown of creation"), anarcho-transhumanism, alluding to post-humanism, emerges as its libertarian variety.

A-H+ builds a catalog of potential spaces in which conscious subjects' liberatory aspirations may be realized. ${ }^{38}$ The ongoing processes of robotization and computerization are responsible for the fact that human labor is less and less dependent on an individual's physical strength, while his or her specialized competences are more and more in demand. As a result, we work less and less, the effects of which include the gradual shift from human labor to machine labor and the birth of post-scarcity economy, based on universal basic income. Eventually, as the outcome of these processes, the society will be relieved from the need of gainful employment. ${ }^{39}$

35. An Anarchist-Transhumanism Manifesto.

36. Anarcho-transhumanism sketches out a long history of its movement, seeing a coincidence between thinking in terms of technological progress and freedom in movements such as the Russian avant-garde and cosmism, cyberfunk, Afrofuturism or even cybernetics. Marcolli, drawing her inspiration from the philosophy of Friedrich Nietzsche, interprets the idea of the superman as a harbinger of the posthuman. In her interpretation, among others, she relies on the following passage: "Man is a rope stretched between the animal and the Superman - a rope over an abyss. A dangerous crossing, a dangerous wayfaring, a dangerous looking-back, a dangerous trembling and halting. What is great in man is that he is a bridge and not a goal: what is lovable in man is that he is an OVER-GOING and a DOWN-GOING." Friedrich Nietzsche, Thus Spake Zarathustra, trans. Thomas Common, Project Gutenberg Etext, December, 1999, http://www.dominiopublico. gov.br/download/texto/gu001998.pdf (20.03.2021).

37. An Anarchist-Transhumanism Manifesto

38. One can easily notice the affinities between anarcho-transhumanism and the movement of technoprogressivists, associated, among others, with the Institute for Ethics and Emerging Technologies. See: Technoprogressive Declaration - Transvision 2014, https://ieet.org/index.php/ IEET2/more/tpdec2014 (15.06.2020).

39. Jacek Dukaj writes about it convincingly, pointing, among others, to the consequences of the "de-laborization" in the perspective of "occupation engineering." See: Jacek Dukaj, Po piśmie [After Writing] (Kraków: Wydawnictwo Literackie, 2019), 57-90. 
The increase in the service sector's share in the economy, the decrease in the importance of manual labor, the democratization of the West, and the universalization of the availability of contraceptives - all these factors brought on a combined effect of liberating women from the compulsion to reproduce, enabling them to take up paid work, and making their participation in meritocracy possible. Some of the bolder ideas in the anarcho-transhumanist repertoire project the possibility of starting post-traditional families (also in terms of reproduction). This, of course, requires a reformulation of the legal system that would allow for the conclusion of wider, and more functional, partnerships, with a view to "design[ing] a modular structure of contracts to enable a whole spectrum of legal relationships between whatever groups of people [...]." ${ }^{\prime 40} \mathrm{This}$, in turn, is but a step away from calling into existence a new dimension of cohousing, which would consist in the joint occupation of space by an arbitrarily constructed constellation of people, whose functioning would be regulated by a partnership agreement. Such a post-traditional structure, owing, among others, to its quick reconfigurability, allows for the separation of economic relations from relations concerning procreation and child-rearing. ${ }^{41}$ The advancement of technology can therefore free people both from the compulsion to reproduce and from the capitalist fetish of productivity. This is one of the possible ways in which technology may liberate humankind from the necessities of generating income and reproducing - necessities that have defined the human thus far.

However, the libertarian critique of technology is, one would be inclined to say, double-edged. On the one hand, it warns us against our own enslavement by technology; on the other - it cautions us to be wary of the dangers of us enslaving technology. ${ }^{42}$ If we assume that consciousness emerges in systems characterized by the sufficient complexity of links among individual component subsystems of a given system (for instance, among the neurons in the brain), we must, consequently, acknowledge that consciousness as such is gradable. ${ }^{43}$ Therefore machines, even if bestowed only with limited consciousness, cannot be exploited as slave labor. ${ }^{44}$

40. Eleanor Saitta, Designing the future of sex, https://theanarchistlibrary.org/library/eleanor-saitta-designing-the-future-of-sex (16.06.2020).

41. Saitta, Designing the future of sex.

42. For instance, positing that "Cyborg persons, and the technology they rely upon, should be free from external influence that is not voluntary. That is, technologies such as prosthetic limbs, organs, etc., should be constructed in a manner as to provide their users with ultimate control of their own body and its extensions." An Anarchist-Transhumanism Manifesto.

43. An Anarchist-Transhumanism Manifesto.

44. On the one hand, one feels the fear of robots or AI, intuitively perceiving them as their successors. On the other hand - throughout history the white, heterosexual (European) man would conquer, dominate and exploit all Others while realizing his aspirations to profits and power. It may, therefore, be suspected that conscious non-anthropic subjects will share the fate of other colonized peoples. 
Such is the post-humanist, ethical dimension of transhumanism, emphasized in the libertarian trends, and founded upon the principle of the equality of all conscious entities. Consequently, also the algorithm that optimizes production, economy, or even social life, must not only be self-governing, but also controlled by those whom it manages. Radical democracy should therefore apply to all conscious and feeling subjects.

The optimistic, libertarian character of anarcho-transhumanism is also revealed in the projected system of democratic circulation of information and knowledge (digital rights), based mainly on the digital forms of knowledge transfer. The Internet would thus support not only the activities of federations or syndicates but it would also provide a safe space for broadly understood minorities to associate. In line with this tendency must be the development of open source and free software. Needless to say, the academe ${ }^{45}$ and education sensu largo play a significant role in the process: only an educated society can be conscious in making decisions.

Particularly important in the context of my further reflections are the forms of non-violent resistance that A-H+ adopts - forms rooted in the legacy of civil disobedience and passive resistance.

Although [anarcho-transhumanism] is non-violent, we are not ignorant of class conflict, frequently referred to as class warfare or class struggle [...]. Diverse direct action tactics against the state and its protected neoliberal capitalist system are of the utmost importance. ${ }^{46}$

One of such non-violent tactics of diversion is the so-called hacktivism, a new form of social activism which relies upon the use of the new technologies, particularly the Internet. The wide gamut of non-violent, freedom-oriented conceptions, movements, and practices also includes cyberfeminism, its more radical form referred to as xenofeminism, ${ }^{47}$

45. Matilde Marcolli points to the burning issues of contemporary academia: the "Publish or Perish" policy, the grant system, the paths of professional career advancement, the entanglement of the academe in the interests of corporations and the military. Such tendencies have a negative effect on the academic community, but also adversely affect scholarship and science as such. Cf. The Slow Science Manifesto, http://slow-science.org, (14.06.2020).

46. An Anarchist-Transhumanism Manifesto.

47. Xenofeminism posits the awareness of the risks related to technology, which "isn't inherently progressive." Simultaneously, it places its hope in it: "Our lot is cast with technoscience, where nothing is so sacred that it cannot be reengineered and transformed so as to widen our aperture of freedom, extending to gender and the human. To say that nothing is sacred, that nothing is transcendent or protected from the will to know, to tinker and to hack, is to say that nothing is supernatural. 'Nature' - understood here, as the unbounded arena of science - is all there is. And so, in tearing down melancholy and illusion; the unambitious and the non-scaleable; the libidinized puritanism of certain 
or postgenderism, ${ }^{48}$ the latter stressing ways in which technology favors the gradual cancellation of (biological) sex and (cultural) gender. ${ }^{49}$ Although these currents differ in their specific assumptions, they share a libertarian, emancipatory character and a critical distance towards monocentric orders, which is why an alliance with them - even if only partial - fits in with the strategies of nomads, which are soon to be discussed.

However, despite the critical distance with respect to technology emphasized in the Manifesto (and other texts), it is easy to misconstrue anarcho-transhumanism as a variety of accelerationism (in the context of capitalism) or Prometheism (in the context of technology). Acceleration projects are either based on the exploitation of the expansion of a given system for their own purposes (according to the principle that the tide raises all boats), or on waiting for this system to collapse due to its internal overheating. Such projects are lined with naivete: the system will not devour its own tail. What is more, investing in it will only reinforce it and, consequently, intensify the oppression generated towards individuals and communities. ${ }^{50}$ Irrespective of the fact that he appreciated the holistic nature of xenofeminism, ${ }^{51}$ such a critique against acceleration systems was leveled, among others, by Alexander Galloway ${ }^{52}$ in his discussion on Inventing the Future ${ }^{53}$ by Nick Srnicek

online cultures, and Nature as an un-remakeable given, we find that our normative anti-naturalism has pushed us towards an unflinching ontological naturalism. There is nothing, we claim, that cannot be studied scientifically and manipulated technologically." Laboria Cuboniks, Xenofeminism. A Politics for Alienation, section 0x11, "Adjust," https://laboriacuboniks.net/manifesto/xenofeminism-a-politics-for-alienation (15.06.2020). Xenofeminism is, therefore, "vehemently anti-naturalist," because "[e]ssentialist naturalism reeks of the ology - the sooner it is exorcised, the better." Laboria Cuboniks, Xenofeminism. A Politics for Alienation, section 0x01, "Zero." Furthermore, "[x]enofeminism is gender-abolitionist. [...] Let a hundred sexes bloom!" Laboria Cuboniks, Xenofeminism. A Politics for Alienation, section 0x0E, "Parity." Such a project requires the redefinition of the universals: "Intersectionality is not the morcellation of collectives into a static fuzz of cross-referenced identities, but a political orientation that slices through every particular, refusing the crass pigeonholing of bodies." Laboria Cuboniks, Xenofeminism. A Politics for Alienation, section 0x0F, "Parity."

48. George Dvorsky, James Hughes, Postgenderism: Beyond the Gender Binary, https://ieet. org/archive/IEET-03-PostGender.pdf (16.06.2020).

49. Therefore, not unlike body modifications, they sex and gender would be forms of expression. See: Anders Sandberg, "Morphological Freedom. Why We Not Just Want It but Need It," in: The Transhumanist Reader. Classical and Contemporary Essays on the Science, Technology, and Philosophy of the Human Future, ed. Max More, Natasha Vita-More (Hoboken: Wiley-Blackwell, 2013), 56-64.

50. Dukaj writes about yet another effect - the subjectification of technology, see: Dukaj, Po piśmie, 9-10.

51. Alexander. R. Galloway, Brometheanism, http://cultureandcommunication.org/galloway/ brometheanism, (28.11.2020).

52. Galloway, Brometheanism.

53. Nick Srnicek, Alex Williams, Inventing the Future. Postcapitalism and a World Without Work (London, New York: Verso, 2015). 
and Alex Williams. Therefore, it is important to constantly emphasize the need for a critical distance - conceived also as mistrust towards one's own discourse both in the cases of narratives skeptical of technology (i.e., perceiving technology only as oppression) and narratives of affirmative, techno-enthusiastic nature. It should be noted, however, that the majority of such discourses are no longer so unambiguous today as they were, for example, in the 1990s; narratives of this type have since developed a degree of critical self-awareness.

\section{Nomadic Subjects of Queer Identities}

The rapidly accelerating technological progress, especially progress related to the development of various types of network connections, radically changes the conditions in which an average Westerner functions. Software and hardware become miniaturized prostheses that mediate his or her interactions with their environment - specialized applications count one's calories, one's hours of sleep, or remind one to change the water filter in the kitchen. The labor of the muscle, the work of memory, and effort of attention alike are being taken over by the technology, effectively rendering the person who interacts with it a hybrid subject.

Within the horizon of our experience, it is more and more often that we operate with what is virtual, not material. In consequence, our perception of temporality changes (as we become engaged in a greater number of short-term activities than ever before) and we redefine the category of place (as software becomes the location of our activities with an increasing frequency). Access to information and entertainment is almost instantaneous, as are our cyberspace-mediated interpersonal contacts (including sexual relations). Along with the advancement of the dematerialization of money - most tangibly felt in the context of online shopping and virtual micropayments - it is not only our work, but also our earnings that gradually shift into the dimension of immateriality. All of the above influences our involvement in our community life: rather with our actual social groups, today we identify with virtual tribes. Nothing stands in our way to fully participate in the lives of several of them at the same time, and nothing prevents us from adopting a different avatar - understood not only as our visual representation, but also as a particular set of traits, behaviors, attitudes, and languages - for the purpose of our interaction within each of these groups. As a result, compelled to increasingly quickly negotiate their uniqueness with the technology-mediated, aggressively stimulating environment, our identities become liquefied. The above notwithstanding, let us try to sketch out some of the affirmative projects of the transhuman subject and his or her identity to observe positive aspects of the technological developments of the recent decades. 
The dynamics of these projects is perhaps best approximated by the traits of Rosi Braidotti's nomadic subject, the subject emerging in postmodernity, in which era "the shift away from manufacturing toward a service and information-based structure entails a global redistribution of labor" ${ }^{\prime 4}$ and, as a result, the subject's identity is determined by the reformulation of the traditional orders of the state, family, and patriarchy. The nomadic subject is founded on empathy, compassion, ${ }^{55}$ and feminist imagination, in which concepts central to such diverse narratives as those offered by Luce Irigaray (female morphology) and Donna Haraway (the figuration of the cyborg) play an important role. Above all, however, the nomadic subject is rooted in corporal materiality. "The body, or the embodiment, of the subject is to be understood as neither a biological nor a sociological category but rather as a point of overlapping between the physical, the symbolic, and the sociological. ${ }^{56}$ Notably, such a proclamation is a gesture of the radical rejection of essentialism.

Thus, the nomadic subject manifests itself as a political fiction that allows Braidotti "to think through and move across established categories and levels of experience: blurring boundaries without burning bridges." "It "I is the subversion of set conventions that defines the nomadic state, not the literal act of traveling," ${ }^{\prime 3}$ and the refore nomadism conceived in this way consists in "the construction of new forms of interrelatedness and collective political projects." ${ }^{\text {" In }}$ the light of Braidotti's "philosophy of 'as if," the flow of connections "marks transitions between communicating states or experiences. [...] Nomadic becoming is neither reproduction nor just imitation, but rather emphatic proximity, intensive interconnectedness." ${ }^{0}$ Thus, the performative, intransitively becoming, creative, nomadic subject carries with him- or herself the history of all transitions and reformulations; he or she is simultaneously en route and trans-, affirming the practice of intervals, interfaces, and interstices, ${ }^{61}$ defined by parody and mimesis. This practice draws one's attention both "to identity as a set of identifications and to political subjectivity as the quest for sites of resistance." ${ }^{2}$ The nomad is therefore a subject who has relinquished fixity. "This figuration expresses the desire for an identity made

54. Rosi Braidotti, "Introduction: By Way of Nomadism," in: Nomadic Subjects. Embodiment and Sexual Difference in Contemporary Feminist Theory (New York and Chichester, West Sussex: Columbia University Press, 1994), 2.

55. Braidotti, "Introduction: By Way of Nomadism," 2-3.

56. Braidotti, "Introduction: By Way of Nomadism," 4.

57. Braidotti, "Introduction: By Way of Nomadism," 4.

58. Braidotti, "Introduction: By Way of Nomadism," 5.

59. Braidotti, "Introduction: By Way of Nomadism," 5.

60. Braidotti, "Introduction: By Way of Nomadism," 5.

61. Braidotti, "Introduction: By Way of Nomadism," 6.

62. Braidotti, "Introduction: By Way of Nomadism," 22. 
of transitions, successive shifts, and coordinated changes, without and against an essential unity," ${ }^{63}$ while its cohesion is warranted by "definite, seasonal patterns of movement through rather fixed routes," ${ }^{4}$ emulating the Deleuzian figure of the rhizome. "The nomad's relationship to the earth is one of transitory attachment and cyclical frequentation; the antithesis of the farmer, the nomad gathers, reaps, and exchanges but does not exploit." ${ }^{\prime 65}$

As an anarchic subject, the nomad opposes the forms of power and oppression that have formed around the city since the Neolithic revolution. Such a power was based on written law, the distribution of goods (i.e., the principles of economy and the tax system), the regulation of space (i.e., the urban layout within the city walls), and religious worship. The situation, however, is more complex. In their manifesto Liberate not Exterminate, the New York-based "action-orientated international anarchist cabal," Curious George Brigade, comes to the city's defense. Although it is the seat of modern capitalism and state power, the city is also the place where people live and work, and so, optimistically, the Brigade proclaims that "We have to confront the enemy at their fortress, if we take away their fortresses they will cease to exist." ${ }^{\prime 6}$ Therefore, the city should not be abandoned; instead, it ought to be re-conceived. Cities teem with life - they are populated with people, animals, and other life forms, sometimes representing unique, endemic species. Designed ecologically, cities do not have to generate pollution. They can be thought of as a set of open spaces governed by a different system of justice and economy a system based on active participation of particular groups and their mutual support. More importantly, however:

Cities are natural reserves of cultural diversity, one can walk through the neighborhoods of London, New York, Port Au Spain, or Hong Kong and experience not only ethnically distinct areas but new hybrids of intermingled cultural identities. Linguistical, cultural, ethnic and stylistic variants are in continual dialog with each other in the healthy city. The city allows these diverse communities to cross-pollinate and create new more flexible identities that enlarge everyone's horizons. Out of these fusions can come a multitude of resistances to the suffocating hegemony of capitalist and nationalist conformity. [...] The cities allow us to reinvent our lives and create new families. It allows us to join our desires of freedom with others creating communities of personal and communal liberation. ${ }^{67}$

63. Braidotti, "Introduction: By Way of Nomadism," 22.

64. Braidotti, "Introduction: By Way of Nomadism," 22.

65. Braidotti, "Introduction: By Way of Nomadism," 25.

66. Curious George Brigade, Liberate not Exterminate, https://theanarchistlibrary.org/library/ curious-george-brigade-liberate-not-exterminate (16.06.2020).

67. Curious George Brigade, Liberate not Exterminate. 
The New York collective, although the tone of its manifesto suggests that they favor the ecological postulates of primitivists, criticizes the violence of hunter-gatherer cultures on account of the latter's inherent sexism, domestic violence, long working hours, hierarchism, and exclusive shamanism. "City-dwellers," the Brigade claims, "are no less or more capable of creating egalitarian and non-hierarchical structures than any other humans." ${ }^{\prime 68}$ It therefore seems that the trajectories of the movement of the post-modern, post-anthropocentric nomad are much more complex than one might suppose at first glance. They traverse vast expanses of fields and forests, as well as narrow city streets; the interior and the exterior; the libertarian positions and the positions of power/capital. Since there is no place outside the logic of power, the subject relinquishes the search for a permanent point of resistance lest to fall into the "trap of a place" and to reconstitute power structures. Thus, the nomadic subject eludes essentialisms ${ }^{69}$ Movement is the nomad's salvation: he or she cannot stop anywhere for long without running the risk that the system will solidify his or her position/location as a point of resistance, and so, like a grasshopper evading his predators, he or she must incessantly change their whereabouts. At the same time, a nomad must be sensitive to the subtle discourses of violence; following the logic of the arms race, he or she must constantly refine his/her critical and discursive weaponry, and - not unlike a terrorist - take over the weapons of his or her opponent only to abandon them immediately after use. Evidently, thus, the non-obvious trajectories of movement prove to be the most important strategies of the nomad's resistance.

At this point, it seems appropriate to ask about the identities of such nomadic subjects. It appears that they can take queer forms, with the provision that the attribute "queer" is understood as a way of thinking about identity in general (not only sexual), emphasizing its variable, relatively non-normative nature. ${ }^{70}$ Thus, queer identities are changeable, situational, and flexible; they contain the history

68. Curious George Brigade, Liberate not Exterminate. More on the relation between anarcho-primitivism and anarcho-transhumanism in: William Gillis, 15 Post-Primitivist Theses, https:// theanarchistlibrary.org/library/william-gillis-15-post-primitivist-theses (17.06.2020).

69. See Saul Newman, From Bakunin to Lacan: Anti-Authoritarianism and the Dislocation of Power (Lanham: Lexington Books, 2001).

70. The relationship between post-anarchism and queer was interestingly summarized by Rafa Majka: "What connects post-anarchism and queer is primarily the so-called poststructural turn, which manifests itself in both projects' critique of the (liberally understood) subject, of the essence, and of traditional forms of identity logic." - Rafał Majka, "Postanarchistyczny queer/queerowy postanarchizm - perspektywy radykalnej polityki we współczesnym systemie-świecie” [Postanarchist Queer/Queer Post-anarchism: Perspectives of Radical Politics in the Contemporary World-System] in: Strategie queer. Od teorii do praktyki, ed. Mariusz Drozdowski, Monika Kłosowska, Agata Stasińska (Warszawa: Difin, 2012), 124. For a more detailed description of the relations between queer, cyberfeminism and anarcho-transhumanism, see: Kyle Munkittrick, "On the Importance 
of their own transitions. Identity conceived in this way may be another libertarian resistance strategy in the nomadic subject's arsenal. Edward Avery-Natale demonstrates this clearly in his analysis of the stance adopted by the Black Bloc protesters at the G20 summit in Pittsburgh in 2009. The scholar interprets the slogan "We are here! We're Queer! We're anarchists, we'll fuck you up!" under which the marchers, (traditionally) dressed in black and wearing masks, protested, as an instance of an occasional identification. Such an identification

[...] demonstrates the postmodern fluidity of identitarian subjectivities. The subject is capable of embracing a multitude of subject positions for identification, and then equally capable of casting any one of these same identifications away when it no longer serves the individual. ${ }^{71}$

This strategy describes the condition of contemporary, postmodern subjects. Wearing "empty" black masks (aside from the fact that the masks make it difficult for the public security services to identify individual protesters) facilitates the adoption of various, occasional identities. ${ }^{72}$ Referring to Deleuze and Guattari, Avery-Natale states that the gesture of putting on the mask obliterates the signifier of the subject and allows for its new representation to be constituted. ${ }^{73}$

The Black Block made no demands during the protests, which was an example of a new wave, anarchist strategy: to be excluded, one must first be included. At the same time, without making demands, it is impossible for the discursive machine of power to inscribe one into its own conceptual horizon and, consequently, to place one in a position advantageous for the machine's own purpos-

of Being a Cyborg Feminist," Anarcho-Transhuman. A journal of radical possibility \& striving, issue 1, https://anarchotranshuman.org (16.06.2020). See also other texts in the above quoted issue.

71. Edward Avery-Natale, "We're Here, We're Queer, We're Anarchists': The Nature of Identification and Subjectivity Among Black Blocs," Anarchist Developments in Cultural Studies, 1/2010, 96.

72. I believe that the Anonymus activists cover their faces in a similar gesture. They use masks depicting Guy Fawkes, the ringleader of the Gunpowder Plot of 1605 whose image was popularized in the film V for Vendetta (directed by James McTeigue, Germany-USA-UK, 2005), based on the comic book by Alan Moore and David Lloyd. I also think that other uniforms present in pop culture perform a similar function: red costumes and masks with Salvador Dali's image worn by the protagonists of the Money Heist (La casa de papel - a Spanish heist crime drama television series created by Álex Pina), the Netflix production of which featured the song of the anti-fascist Italian partisans Bella ciao, giving it another life. Another example is that of the red capes and white caps of the protagonists of the TV series The Handmaid's Tale (USA, 2017) based on the novel by Margaret Atwood.

73. In the psychoanalytic perspective, the face is also a mask - one allowing the subjectivity to appear as something. The black mask, then, is tantamount to one's confrontation with one's own de-subjectified Other. See Avery-Natale, “'We're Here, We're Queer, We're Anarchists'..., 103. 
es. ${ }^{74}$ This gesture is of paramount important also because the protesters shifted the emphasis of the protest from demands to being - being open to the future, as Giorgio Agamben understood the concept. In black clothes and black masks they could be whatever.

Avery-Natale argues, however, that just as deterritorialization requires reterritorialization, so the abandonment of one subjectivity requires re-subjectification (e.g., the protesters, wearing masks, became anarchists). We cannot rest in our nomadic movement, we cannot deterritorialize ourselves out of subjectivity. ${ }^{75}$ The protesters "represent that which may be but is not yet here," and then pull off their masks. Yet, the above notwithstanding, the very act of donning them is a queer gesture that negates empowerment/subjectification/identification as such, and is therefore a step towards the freedom to be whatever. On the path towards this desired state, however, destruction is unavoidable: it is necessary to obliterate not only the existing order (e.g., the order of capitalism, as was the case with the protests against the G20), but also ideology - including the anarchist ideology, which, in the end, also limits the subject. ${ }^{76}$ Thus, the Black Block G20 protest may serve as an example of a critical approach to one's own discourse a reification of yet another element of the libertarian strategy.

A nomadic queer subject may also be, as Shaun Bartone calls them, a "strange attractor." 77 The chaos theory assumes that the processes generating structures also produce chaos: in biological life, for instance, mutations are a case in point. These, in turn, "indicate a capacity for interaction with the environment that produces structural change," 78 thus, in a sense, making evolution possible. This rule may also be applied to social systems replicating by way of biological and cultural reproduction. Bartone introduces the figure of "queer-as-chaos" thus:

The 'queer' then, is an intentional resistance to heteronormativity, an augmentation of difference further differentiates us from the social system. Queer-as-chaos is the eruption of that difference into heteronormative systems to the extent that it destabilizes the system's mechanisms of controlled replication. ${ }^{79}$

74. Avery-Natale, “'We're Here, We're Queer, We're Anarchists'...," 99.

75. Avery-Natale, “We're Here, We're Queer, We're Anarchists'...," 105.

76. Avery-Natale, “We're Here, We're Queer, We're Anarchists'...," 109.

77. "A strange attractor is a chaotic set with a fractal structure that is non-linear and never repeats." - Shaun Bartone, "Strange Attractors: Queer, Chaos, and Evolution," Anarchist Developments in Cultural Studies, 1-2/2015, 38. Such attractors, albeit determined, are unpredictable, emerging at when a given system loses stability.

78. Bartone, "Strange Attractors: Queer, Chaos, and Evolution," 33.

79. Bartone, "Strange Attractors: Queer, Chaos, and Evolution," 34. 
As such, queer-as-chaos disrupts the heteronormative homeostasis. It has the potential to undermine social and cultural systems, and - above all - to transform them. If, however, one chooses to see these systems through an evolutionist's eyes, they will conclude that the driving forces of change are divergence and diversity: two factors that enforce the formation of new ways of expression and cognition, propel new languages and new aesthetics. Yet, nonetheless, the impulse for change, the strange attractor, owing to which the system evolves - is queer-as-chaos.

The "queer" then, is an intentional resistance to heteronormativity, an augmentation of difference that further differentiates us from the social system. Queer-as-chaos is the eruption of that difference into heteronormative systems to the extent that it destabilizes the system's mechanisms of controlled replication. ${ }^{80}$

The queer introduces a moment of chaos, a moment of catastrophe, which, as Bartone understands it, is the moment of the opening of new paths, the possibility of new trajectories, ${ }^{81}$ the starting point of new evolutionary cycles. "Queeras-chaos is an un-identity. It is an identity that never stabilizes, never solidifies. It is a dynamical identity that constantly shifts, changes, and evolves over time," 82 it is the "refusal of the identity" the society would expect one to embrace. This strange attractor reduces the categories of time and space to the ever-present "here and now," ${ }^{83}$ and thereby "[q]ueer (r)evolution does not promise a 'better' future, only a different one." 84 It is the future, made feral again, that endangers the wild and the tame alike. ${ }^{85}$

Born in the peripheries, creative, queer-as-chaos works in language, creating new codes and meanings, because moving between the dominant and the marginal codes, it neither identifies with any, nor does it reject any. ${ }^{86}$ Queer-as-chaos is tantamount to the stance opposing heteronormativity - but also undermining race, gender, class, and other monocentric orders. Bartone lists examples - the case of Pussy Riot, Chelsea Manning, or Brandon Teena - whose power of impact proved to cause the butterfly effect.

The question "What will the future be like?" should remain unanswered if we do not want it to be appropriated and inscribed into the conceptual horizon of the system of power. Nonetheless, the future has been described on numer-

80. Bartone, "Strange Attractors: Queer, Chaos, and Evolution," 39.

81. Bartone, "Strange Attractors: Queer, Chaos, and Evolution," 39.

82. Bartone, "Strange Attractors: Queer, Chaos, and Evolution," 41.

83. Bartone, "Strange Attractors: Queer, Chaos, and Evolution," 58.

84. Bartone, "Strange Attractors: Queer, Chaos, and Evolution," 59.

85. Bartone, "Strange Attractors: Queer, Chaos, and Evolution," 62.

86. Bartone, "Strange Attractors: Queer, Chaos, and Evolution," 52. 
ous occasions. One of such visions is, for example, Giorgio Agamben's vision of the "coming" community of undifferentiated individuals, people undetermined by identities - a community of whatevers who devote themselves to being: "[t]hese pure singularities," Agamben explains, "communicate only in the empty space of the example, without being tied by any common property, by any identity. They are expropriated of all identity, so as to appropriate belonging itself [...]," ${ }^{87}$ and

Whatever is the figure of pure singularity. Whatever singularity has no identity, it is not determinate with respect to a concept, but neither is it simply indeterminate; rather it is determined only through its relation to an idea, that is, to the totality of its possibilities. ${ }^{88}$

While it would be difficult to unequivocally put forward any thesis about Agamben's critical or affirmative attitude to what is to come, Jacek Dukaj's concept of the future, presented in his 2019 collection of essays Po piśmie [After Writing], is a function of the critical position he adopts. Retracing the evolution of the techniques serving the purpose of the transmittal of experiences, the author of Ice heralds the coming of the post-literate era, inhabited by biological experiencing machines, "hollow experiencers," who, perceiving reality through adjectives, will qualify transferred experience as truth. ${ }^{89}$ An era, in which the lifestyle, the art of life, will flourish.

\section{The Strategies of a Queer Nomad}

Posthumanism, post-structural anarchism, and the wide constellation of anarcho-transhumanist discourses seeing a liberatory potential in technoscience, allow one not only to define human subjectivity in the era of the postmodern, transnational capitalism, but also to determine it in the perspective of the networked media reality, in which, at any moment, we may encounter non-anthropic, yet conscious subjects.

We are (or may be) digital nomads ${ }^{90}$ who do not so much follow the digital rhizome as let it move before our eyes ${ }^{91}$ in a series of post-literate images, linked

87. Giorgio Agamben, The Coming Community, trans. Michael Hardt (Minneapolis and London: University of Minnesota Press, 2007), nn.

88. Agamben, The Coming Community, nn.

89. Dukaj, Po piśmie, 210-212.

90. The concept of the digital nomad is also used to describe people who, working remotely, can freely move around the globe. As such, in a sense, they are double nomads: they travel the material and the digital worlds at the same time. A nomadic subject may also bridge the (generation-bound) opposition between the digital natives and digital immigrants.

91. Cf. Gilles Deleuze, Felix Guattari, A Thousand Plateaus. Capitalism and Schizophrenia, trans., and foreword by Brian Massumi (Minneapolis and London: University of Minnesota Press, 1987), 351-423. 
by unknown logics generated by - perhaps already partially conscious - algorithms. At almost zero-time intervals, we visit places, interact with our tribes, and constantly negotiate our fluid, flexible, adjectival identities. Not driven by any necessity, we are free to choose from among their variety according to our will, or following our need of self-expression. Thus, we exploit fragments of libertarian, emancipatory discourses; almost-already, we are whatever.

We have adopted (or may adopt) fluid, situational, occasional identities. A queer-nomad/queer-as-chaos not only remains elusive to the mechanisms of discursive inclusion, but also escapes the danger of the disintegration of places that have temporarily provided support by resorting to a series of short dis/placements. Queer nomadism is an impulse for change: it opens the system to new cycles and new possibilities. It is a strategy of resistance: being whatever helps one to conceive of resistance beyond the opposition of cynical (or naïve) accelerationism and partisan antagonism.

Of course, all this is possible provided that we are sensitive to the subtle influence of power through immediatized messages, and - above all - on condition that we keep a critical distance, especially with regard to the strategies that we ourselves adopt. Discursive terrorists, who have learned many languages in the course of their motionless journey, deploy them against various forms of domination - only to abandon them immediately after use.

Translated by Paweł Jędrzejko

(D) https://orcid.org/0000-0002-3251-2540 


\section{Bibliography}

“An Anarchist-Transhumanist Manifesto." https://docs.google.com/document/d/1wJrXYBXAmNH9zwyfgg1-yAYN_Cda-26pFCk0u_QhyBc/edit (03.06.2020).

“Technoprogressive Declaration - Transvision 2014.” https://ieet.org/index.php/IEET2/ more/tpdec2014 (15.06.2020).

“The Slow Science Manifesto.” http://slow-science.org (14.06.2020).

Agamben, Giorgio. The Coming Community. Translated by Michael Hardt. Minneapolis and London: University of Minnesota Press, 2007.

Agamben, Giorgio. What Is an Apparatus? And Other Essays. Translated by David Kishik and Stefan Pedatella. Stanford CA: Stanford University Press, 2009.

Avery-Natale, Edward. "'We're Here, We're Queer, We're Anarchists': The Nature of Identification and Subjectivity Among Black Blocs.” Anarchist Developments in Cultural Studies, no. 1, 2010, 99-115.

Bartone, Shaun. "Strange Attractors: Queer, Chaos, and Evolution.” Anarchist Developments in Cultural Studies, no. 1-2, 2015, 31-72.

Bednarek, Joanna. "Zwrot posthumanistyczny a ontologia." Praktyka Teoretyczna, vol. 14, no. 4, 2014, 247-255.

Bey, Hakim. Immediatism. Edinburgh: AK Press, 1994.

Braidotti, Rosi. "Introduction: By Way of Nomadism." In: Nomadic Subjects. Embodiment and Sexual Difference in Contemporary Feminist Theory. New York and Chichester, West Sussex: Columbia University Press, 1994.

Braidotti, Rosi. "Posthuman Relational Subjectivity and the Politics of Affirmation." In: Relational Architectural Ecologies. Architecture, Nature and Subjectivity, edited by Peg Rawes, 21-39. London and New York: Routledge, 2013.

Braidotti, Rosi. "Posthuman, All Too Human. Towards a New Process Ontology," Theory, Culture \& Society, vol. 23, no. 7-8, 2006, 197-208.

Braidotti, Rosi. “The Politics of Life as Bios/Zoe.” In Bits of Life. Feminism at the Intersections of Media, Bioscience, and Technology, edited by Anneke Smelik and Nina Lykke, 177-192. Seattle and London: University of Washington Press, 2008.

Braidotti, Rosi. "Working towards the Posthumanities." Trans-Humanities, vol. 7, no. 1, 2014, 155-175.

Call, Lewis. "Editorial - Post-anarchism Today." Anarchist Developments in Cultural Studies, no. 1 (2010), 9-15.

Chappie, dir. Neill Blomkamp, Columbia Pictures, South Africa-USA, 2015.

Curious George Brigade. “Liberate not Exterminate.” https://theanarchistlibrary.org/ library/curious-george-brigade-liberate-not-exterminate (16.06.2020).

De la Durantaye, Leland. Giorgio Agamben. A Critical Introduction. Stanford: Stanford University Press, 2009. 
Deleuze, Gilles, and Felix Guattari. A Thousand Plateaus. Capitalism and Schizophrenia. Translated by Brian Massumi. Minneapolis and London: University of Minnesota Press, 1987.

Dolphijn, Rick, and Iris van der Tuin. New Materialism: Interviews \& Cartographies. Ann Arbor: Open Humanities Press, 2012. http://hdl.handle.net/2027/spo.11515701.0001.001.

Dukaj, Jacek. Po piśmie. Kraków: Wydawnictwo Literackie, 2019.

Dvorsky, George, and James Hughes. "Postgenderism: Beyond the Gender Binary.” https:// ieet.org/archive/IEET-03-PostGender.pdf (15.06.2020).

Fabbri, Lorenzo. "From Inoperativeness to Action: On Giorgio Agamben's Anarchism." Radical Philosophy Review, vol. 14, vol. 1, 2011, 85-100.

Galloway, Alexander R. “Brometheanism.” http://cultureandcommunication.org/galloway/brometheanism (11.11.2020).

Gillis, William. “15 Post-Primitivist Theses.” https://theanarchistlibrary.org/library/ william-gillis-15-post-primitivist-theses (17.06.2020).

Gorliński-Kucik, Piotr. "Głos budującego na pustyni. Kryptoteologia gnozy technologicznej.” FA-art., vol. 105, no. 3, 2016, 45-63.

Gorliński-Kucik, Piotr. "Między nadzieją a paranoją. O post-człowieku w filmach science fiction (na kilku przykładach)." Creatio Fantastica, vol. 59, no. 2 (2018), 109-122.

Gorliński-Kucik, Piotr. TechGnoza, uchronia, science fiction. Proza Jacka Dukaja. Katowice: University of Silesia Press, 2017.

Her. Dir. Spike Jonze, USA, 2013.

Heroux, Erick. "PostAnarchia Repertoire." Anarchist Developments in Cultural Studies, no. 1, 2010, 19-30.

Laboria Cuboniks. "Xenofeminism. A Politics for Alienation.” https://laboriacuboniks. net/manifesto/xenofeminism-a-politics-for-alienation (15.06.2020).

Majka, Rafał, "Postanarchistyczny queer/queerowy postanarchizm - perspektywy radykalnej polityki we współczesnym systemie-świecie.” In: Strategie Queer. Od teorii do praktyki, edited by Mariusz Drozdowski, Monika Kłosowska, and Agata Stasińska, 115-133. Warszawa: Difin, 2012.

Money Heist. Atresmedia, Spain, 2017-2021.

Munkittrick, Kyle. “On the Importance of Being a Cyborg Feminist.” Anarcho-Transhuman. A journal of radical possibility \& striving, issue 1. https://anarchotranshuman. org (16.06.2020).

Newman, Saul. From Bakunin to Lacan: Anti-Authoritarianism and the Dislocation of Power. Lanham: Lexington Books, 2001.

Nietzsche, Friedrich. Thus Spake Zarathustra. Translated by Thomas Common. Project Gutenberg Etext, 1999. http://www.dominiopublico.gov.br/download/texto/gu001998. pdf (20.03.2021).

Nowicka, Magdalena. “'Urządzenie,' ‘zastosowanie,' 'układ' - kategoria dispositif u Michela Foucaulta, jej tłumaczenia i ich implikacje dla postfoucaultowskich analiz władzy.” Przegląd Socjologii Jakościowej, vol. 7, no. 2, 2011, 94-110. 
Parnicki, Teodor. Koniec 'Zgody Narodów'. Powieść z roku 179 przed narodzeniem Chrystusa. Ed. II. Warszawa: Instytut Wydawniczy PAX, 1957.

Rousselle, Duane, and Jason Adams. “Anarchism’s Other Scene. Materializing the Ideal and Idealizing the Material." Anarchist Developments in Cultural Studies, no. 2, 2013, 1-9.

Rousselle, Duane, and Süreyyya Evren, ed. Post-Anarchism. A Reader. London: Pluto Press, 2011.

Saitta, Eleanor. "Designing the Future of Sex." https://theanarchistlibrary.org/library/ eleanor-saitta-designing-the-future-of-sex (15.06.2020).

Sandberg, Anders. "Morphological Freedom. Why We Not Just Want It But Need It." In The Transhumanist Reader. Classical and Contemporary Essays on the Science, Technology, and Philosophy of the Human Future, ed. Max More and Natasha Vita-More, 56-64. Hoboken: Wiley-Blackwell, 2013.

Srnicek, Nick, and Alex Williams. Inventing the Future. Postcapitalism and a World Without Work. London, New York: Verso, 2015.

The Handmaid's Tale. MGM Television, USA, 2017-2021.

$V$ for Vendetta, dir. James McTeigue, Warner Bros., USA-UK-Germany, 2005.

WALL.E, dir. Andrew Stanton, Walt Disney Pictures, Pixar Animation Studios, USA, 2008.

Westworld. Bad Robot, USA, 2016-2020. 